\title{
MARKET CONCENTRATION AND PRODUCT VARIETY UNDER SPATIAL COMPETITION: EVIDENCE FROM RETAIL GASOLINE
}

\author{
GEORG GOETZ \\ KLAUS GUGLER
}

\section{CESIFO WORKING PAPER NO. 1289}

CATEGORY 9: INDUSTRIAL ORGANISATION

SEPTEMBER 2004

Presented at CESifo Venice Summer Institute, Workshop on

RECENT DeVElopments In ANTI-TRUSt ANALysis, July 2004

An electronic version of the paper may be downloaded

- from the SSRN website:

www.SSRN.com

- from the CESifo website:

www.CESifo.de 


\title{
MARKET CONCENTRATION AND PRODUCT VARIETY UNDER SPATIAL COMPETITION: EVIDENCE FROM RETAIL GASOLINE
}

\begin{abstract}
We show that for a spatially differentiated economy reduced product variety is the likely outcome of mergers except in cases where exit costs in relation to (outlet-specific) fixed costs are high. Our empirical analysis of the Austrian retail gasoline market confirms that increases in concentration reduce product variety. Ignoring this product variety effect is likely to lead to an underestimate of market power in structural merger analysis.
\end{abstract}

JEL Code: L11, L13, L90.

Keywords: spatial product differentiation, retail gasoline, mergers, concentration.

\author{
Georg Goetz \\ Department of Economics \\ University of Vienna \\ BWZ - Bruenner Str. 72 \\ 1210 Vienna \\ Austria \\ georg.goetz@univie.ac.at
}

\author{
Klaus Gugler \\ Department of Economics \\ University of Vienna \\ BWZ - Bruenner Str. 72 \\ 1210 Vienna \\ Austria \\ klaus.gugler@univie.ac.at
}

We would like to thank Frank Verboven, Bob Rothschild, and the conference participants at the CESifo workshop "Recent Trends in Antitrust Analysis" in Venice, in particular Dan Kovenock, for helpful comments. 


\section{Introduction}

Mergers in spatially differentiated industries are likely to affect product variety. If potential entry matters, mergers may lead to an increase in product variety as shown by Berry and Waldvogel (2001). They find that the consolidation in radio broadcasting following the Telecommunication Act of 1996 led to an increase in product variety measured by the number

of programming formats. However, examples such as mergers among retail banks show that mergers may also reduce the number of branches. ${ }^{1}$

We present theoretical examples for a spatially differentiated economy, which show that reduced product variety is a likely outcome of mergers if barriers to entry are high. This holds except in cases where exit costs are high in relation to (outlet specific) fixed costs. In the empirical analysis, we examine the effect of concentration on product variety in the Austrian retail gasoline market. This market is ideal for testing our hypothesis. First, it exhibits a number of the particular characteristics of a spatially differentiated industry. ${ }^{2}$ Second, entry hardly matters, as Figure 1 shows. The number of stations is steadily decreasing over time, and de-novo entry is nearly absent.

\footnotetext{
${ }^{1}$ After the merger of Bank Austria and Creditanstalt AG in Austria, 70 of the 470 bank branches of the combined firm were closed in 2002.

${ }^{2}$ See Pinkse et al. (2002).
} 


\section{Number of gasoline stations in Austria}

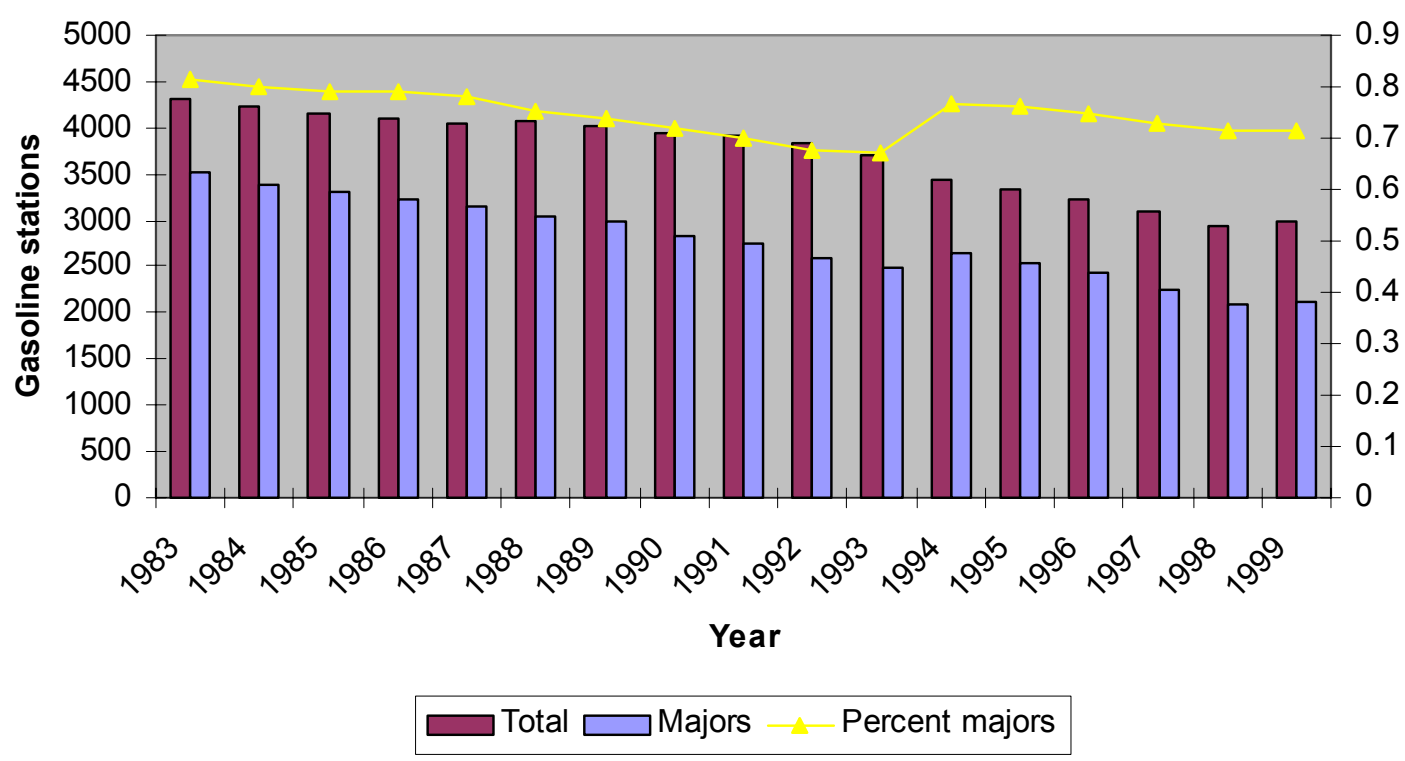

Figure 1

Third, there is considerable merger activity in the market as one can see, for instance, from the large change in the market share of the Majors ${ }^{3}$ from 1993 to 1994 (see Figure 1). In that year OMV AG took over the independent discounter STROH, which operated about 100 stations. Finally, relocation costs are likely to be prohibitive, and exit costs are substantial (see Netz and Taylor, 2002).

These characteristics are not specific to Austria. For example, in Germany only 12,000 out of the currently 16,000 gasoline stations are viable in the long run according to industry lobbyists. The association of the Majors (Mineralölwirtschaftsverband) and the association of the independents (Verband der Freien Tankstellen) together applied on July $10^{\text {th }}, 2001$, at the German antitrust authority (Bundeskartellamt) for authorisation of the establishment of a

\footnotetext{
${ }^{3}$ The six largest oil companies, OMV AG, BP Austria AG, Shell, Esso, Agip and ARAL, are called the Majors.
} 
structural crisis cartel (Strukturkrisenkartell). The goal of the cartel is to support the exit of unprofitable outlets by paying a kind of wreck premium. The payments are to be financed by a surcharge on the wholesale price for all stations. Since the antitrust authority opposes the proposal, mergers might be a device to at least partially avoid what the lobbyists call "structural adjustment via a price war". ${ }^{4}$

Our theoretical examples account for these special features, and our empirical analysis of the Austrian retail gasoline market confirms that increases in concentration reduce product variety (as measured by the number of stations per sqkm). This relation depends on consumer density, and is always negative, except in areas with very low consumer density where no relation between concentration and station density is found. The ratio of exit to fixed costs is likely to be high in these sparsely populated regions, since fixed costs are lower due to lower real estate prices, while exit costs (particularly if they consist mainly of cleaning up costs) are independent of population density.

Our result that more concentrated markets display less product variety has implications for "structural" analyses in empirical industrial organization. Such studies combine assumptions on the pricing behavior of firms with a demand model, which identifies market conduct and thus market power. ${ }^{5}$ They neglect a key feature of market power in

\footnotetext{
${ }^{4}$ The head of the Bundeskartellamt explicitly stated that the recent merger of two majors (BP and ARAL) will lead to closures of stations anyway. See FTD.DE, 25.7.2001, "Wettbewerbshüter gegen Tankstellenkartell". FAZ.net, 28.3.2001, "Immer weniger Tankstellen". Bundesverband Freier Tankstellen, 28.3.2001, "Aktuelles: Interview mit Herrn Müller: Markt für freie Tankstellen wird enger".

${ }^{5}$ See Baker and Bresnahan (1985), Nevo (2000), Ivaldi et al. (2002), Ivaldi and Verboven (2002), Genesove and Mullin (1998). For an early survey see Bresnahan (1989).
} 
differentiated markets, namely that a merger between formerly competing firms may change product variety. Compared to much of the theoretical literature (see, e.g., Pepall et al., 2002, Heywood et al. 2001) our paper explicitly accounts for closure of outlets and examines possible cost synergies in greater detail.

The next section presents our theoretical examples, Section 3 covers the empirical analysis, and Section 4 concludes.

\section{Theoretical examples}

Consider a variant of the traditional Salop (1979) model of a circular city. Consumers are located uniformly on a circle with a perimeter equal to 1 . Density and total population is normalized to 1 . For a consumer whose location and most preferred variety is $\hat{x}$, the (indirect) utility from consuming a good which is sold at a price $p_{i}$ at location $x_{i}$ is

$$
U_{\hat{x}}=a-t\left(x_{i}-\hat{x}\right)^{2}-p_{i} .
$$

The distance $\left(x_{i}-\hat{x}\right)$ is measured by the smallest arc length between $x_{i}$ and $\hat{x}$. Locations $x_{i}$ and $\hat{x}$ are measured by the clockwise arc length between noon and the respective location. The (common) reservation price $a$ is assumed to be large so that all consumers will always buy a product. We choose the indices of the outlets in a way that outlet $i$ is located to the left of outlet $j$, i.e. $x_{i}<x_{j}$, if $i<j$. The consumer $\alpha$ who is indifferent between buying at $i$ and $j$ is defined by the condition

$$
\alpha_{i, j}=\frac{p_{j}-p_{i}}{2 t\left(x_{j}-x_{i}\right)}+\frac{x_{j}+x_{i}}{2} .
$$

\footnotetext{
${ }^{6}$ Note that we denote the consumer who is indifferent between the first firm and the $n^{\text {th }}$ firm, which is to the right of it, as $\alpha_{\mathrm{n}, 1}$.
} 
If prices are such that the market share of all outlets is positive, demand for outlet $i$ equals $D_{i}=\alpha_{i, i-1}+\alpha_{i, i+1}$.

We analyse the effects of mergers and concentration in a framework in which - at most - three firms are active. We assume that each operates only one outlet. In the case of a merger of (at most) two of the three firms, the combined firm may either run one or two outlets. We allow explicitly for the exit of one outlet. With respect to locations we assume that outlets are located equidistantly in the three outlet case (i.e., at $0,1 / 3$, and $2 / 3$ ).

\subsection{Three single product firms}

The profit function of firm $i$ reads

$$
\Pi_{i}=p_{i} D_{i}-f_{i}, \quad i=1,2,3 .
$$

where $f_{i}$ denotes firm $i$ 's fixed costs. Marginal costs are normalized to zero. Straightforward calculations yield the symmetric equilibrium price $p=t / 9$ and profits $\pi_{i}=t / 27-f_{i}$

\subsection{Merger: equilibrium with three outlets}

The case of a merger between firms 1 and 2 that does not lead to outlet closure is depicted in Figure 2.

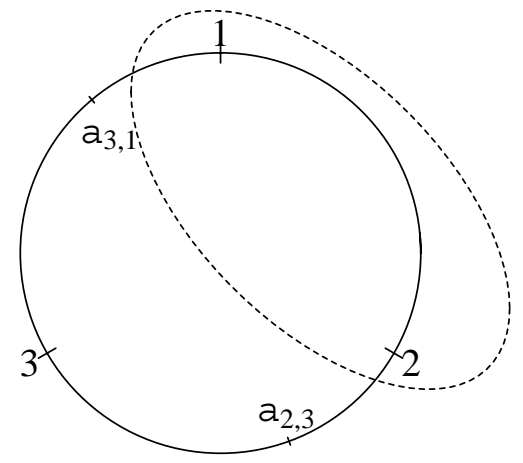

Figure 2: Circular model when firms 1 and 2 merge 
The combined firm's profit function reads

$$
\Pi_{m}=p_{1} D_{1}+p_{2} D_{2}-f_{1}-f_{2}
$$

The combined firm's price, its total output $q_{m}$ and its operating profit $\pi_{m}$, respectively, are as follows:

$$
p_{m}=\frac{5 t}{27}, q_{m}=5 / 9, \pi_{m}=\frac{25 t}{243} .
$$

The respective values for the outsider are

$$
p_{o}=\frac{4 t}{27}, q_{o}=4 / 9, \pi_{o}=\frac{16 t}{243} .
$$

The merger leads to higher prices as the merging firms internalize part of the business stealing implied by the quest for higher market share. Since the outsider responds to the price increase by increasing its own price by less than the combined firm, prices are unequal in equilibrium. The merging firms jointly gain $7 t / 243$ in total operating profits. That is, even without cost reducing synergies the merger is profitable. The profit gain of the outsider is also $7 t / 243$, twice the gain of a merging firm. The profit increase of the outsider is due to both the increase in prices and the increase of its market share. The latter point is obvious from Figure 2, the indifferent consumers $\left(\alpha_{2,3}\right.$ and $\left.\alpha_{3,1}\right)$ are now located closer to the outlets of the combined firm compared to the case with three independent firms.

\subsection{Merger: equilibrium with two outlets}

If the merging firms decide to close one outlet, we can distinguish two cases: a scenario with costless relocation and one in which relocation is (prohibitively) costly. Since the principle of maximum product differentiation applies in our framework, in the first case the outlet of the merging firm would be located at a distance of $1 / 2$ from the outsider. We obtain an equilibrium price of $t / 4$ in this case. Operating profits are $t / 8$. 
Figure 3 shows the situation if relocation is not possible and outlet 2 is closed.

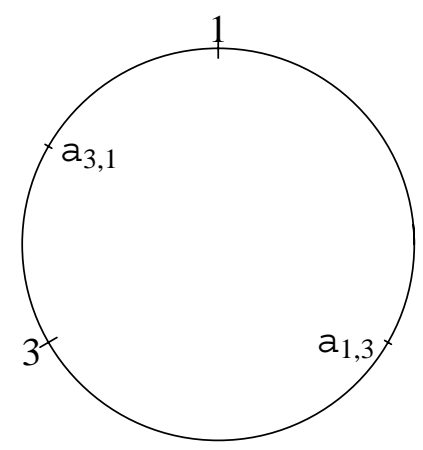

Figure 3: Circular model when the merging firm closes outlet 2 (no relocation)

Now both firms charge a price of $2 t / 9$. The firms' profits are $t / 9$. Although the firms share the market evenly ( $\alpha_{1,3}$ and $\alpha_{3,1}$ are located half-way between the two competitors), price competition is tougher and profits are lower than in the case of (costless) relocation. This is due to the absence of maximum product differentiation as is apparent from Figure 3.

\subsection{Merger: A combined firm with one or two outlets?}

In order to determine the optimum number of outlets, we must be more specific about how (fixed) costs change in the case of a merger. The result is straightforward in the case of costless relocation (i.e., maximum product differentiation in the two outlet case). Operating profits are higher in the case of outlet closure by $t(1 / 8-25 / 243)=43 t / 1944$. Since the fixed costs of the merged entity should at least not be higher if it operates one rather than two outlets, closing one outlet is always profitable if relocation is costless. This result is an application of the result concerning non-optimality of multiple outlets in Martinez-Giralt and Neven (1988).

The result that operating profits of the merging firms are higher with one rather than two outlets holds also in the case without costless relocation. The difference in profits is $2 t / 243$. This value is much smaller than in the case of costless relocation, it amounts to less 
than ten percent of the operating profits. To derive the optimum number of outlets in the case without costless relocation, we distinguish three cases.

1. All potential reductions in fixed costs are realized due to the merger per se, that is without closure of an outlet. Post-merger fixed costs are equal to $f$ in this case if the merging firms operate two outlets. ${ }^{7}$ Since closure of an outlet yields only the (small) gain in operating profits, the existence of small exit costs is sufficient to make two outlets the optimum choice.

2. Fixed costs do not change due to the merger unless an outlet is closed. In this case only exit costs which are greater than the fixed costs would leave the number of outlets unaffected.

3. Parts of the potential cost reductions are realized by the merger without closure of outlets. Suppose that a part of the fixed costs is outlet specific, while the remaining fixed costs are firm specific. The latter costs may be driven by factors such as advertising. In this case the decision on how many outlets to run depends crucially on the relation of outlet specific fixed costs to the exit costs, which are specific to the outlet as well.

Summing up the examples, we conclude that mergers are likely to lead to a reduced number of outlets unless exit costs are high in relation to (outlet specific) fixed costs.

\section{The data and results}

To substantiate this hypothesis we analyse the effects of market concentration on the density of gasoline stations in Austria. We assembled a comprehensive list of gasoline stations in

\footnotetext{
${ }^{7}$ Pepall et al. (2002) also assume that cost structure.
} 
Austria as of the beginning of $2001 .^{8}$ Unfortunately, there is no comprehensive list of stations available from a single source, therefore we had to construct a list from the sources Statistik Austria (Austrian Statistical Office), the ÖAMTC (an Austrian automobile club), and information provided by the petroleum companies (in the order of their market shares) OMV AG, BP Austria AG, SHELL, ESSO, AGIP and ARAL. Thus, we could localize 2,856 gasoline stations in Austria by address (zip code and address). Additionally, we know the name of the oil company operating the stations or whether the station is operated by an independent retailer. According to the Fachverband der Mineralölindustrie (Association of the Petroleum Industry in Austria), there were 2,957 operating gasoline stations in Austria as of the beginning of 2001, thus our list covers $96.6 \%$ of all gasoline stations in Austria.

A rather difficult problem is the delineation of local gasoline markets and the definition of "regions". Austria consists of nine federal states subdivided into 121 districts, which consist of roughly 2,400 municipalities (i.e. zipcode level). We use the districts as relevant regions. This choice compromises on the market definition being too narrow (should we have based it on zip codes, etc.) or too wide (if we took federal states).

For each of the 121 districts, we calculate the density of gasoline stations $S_{k}$ (= number of stations per sqkm in district $k$ ), population density $D_{k}$ (= number of inhabitants per sqkm), the Herfindahl index $H E R F_{k}$ (= squared sum of market shares of all firms operating in district $k$ ), and the four-firm concentration measure $C 4_{k}$ (= sum of market shares of four largest firms).

Several features of the data set are worth mentioning. First, our model of section 2 assumes product differentiation, i.e. stations do not (perfectly) cluster in one location, since price competition would drive profits to zero. This is what we actually observe in the data.

\footnotetext{
${ }^{8}$ Thus we analyse a cross section of markets as Berry and Waldvogel (2001).
} 
For example, in nearly $60 \%$ of the zipcode areas with stations, there is only one station.

Second, we use the number of gasoline stations rather than output or sales as the basis to calculate concentration figures. This has the advantage that our measures of concentration are less subject to the kind of endogeneity problems mentioned by Evans et al. (1993). ${ }^{9}$ Finally, Table 1, Panel A, presents summary statistics. On average, the patch of a service station is 31.4 sqkm $(=1 / S)$. The average $C 4$ is $65.4 \%$ and the average $H E R F$ is $16.8 \%$, with a wide range from 6 to $100 \%$.

Table 1: Results

Panel A: Summary statistics over 121 districts

\begin{tabular}{lrrrrr}
\hline & Mean & Median & St. Dev. & Minimum & Maximum \\
\hline $\mathrm{km}^{2} /$ station & 31.39 & 29.04 & 26.87 & 0.30 & 113.28 \\
Inhabitants $/ \mathrm{km}^{2}$ & 2039.23 & 89.26 & 4988.82 & 21.11 & 26028.63 \\
Herfindahl & 16.77 & 14.05 & 12.54 & 5.87 & 100.00 \\
$\mathrm{C} 4$ & 65.35 & 62.50 & 13.60 & 35.71 & 100.00 \\
\hline
\end{tabular}

${ }^{9}$ Concentration-price regressions suffer mainly from two sources of bias: first, concentration normally is a function of endogenous firm outputs or revenues. Second, performance feeds back into market structure, that is concentration causes price, but price also causes concentration. In this paper we look, however, at the concentration-density nexus, which should suffer much less from endogeneity. 


\section{Panel B: Regression results}

\begin{tabular}{|c|c|c|c|c|c|c|c|c|}
\hline \multicolumn{9}{|c|}{ Dependent variable: $\ln \left(\right.$ stations $\left./ \mathrm{km}^{2}\right)$} \\
\hline \multirow[t]{3}{*}{ Independent variables: } & \multirow{2}{*}{\multicolumn{2}{|c|}{ OLS }} & \multirow{2}{*}{\multicolumn{2}{|c|}{ OLS }} & \multirow{2}{*}{\multicolumn{2}{|c|}{ OLS }} & \multirow{2}{*}{\multicolumn{2}{|c|}{ 2SLS }} \\
\hline & & & & & & & & \\
\hline & Coef & $t$-value & Coef & $t$-value & Coef & $\mathrm{t}$-value & Coef & $\mathrm{t}$-value \\
\hline$\overline{\ln \left(\operatorname{Inhabitants} / \mathrm{km}^{2}\right)}$ & 0.835 & 49.01 & 1.174 & 13.08 & 1.840 & 6.10 & 1.580 & 7.59 \\
\hline $\ln (\mathrm{HERF})$ & -0.306 & -3.79 & 0.426 & 2.07 & & & 1.081 & 1.76 \\
\hline $\ln (\mathrm{C} 4)$ & & & & & 0.803 & 1.77 & & \\
\hline $\ln (\operatorname{Inhabitants})^{*} \operatorname{In}(\mathrm{HERF})$ & & & -0.118 & -3.84 & & & -0.253 & -3.34 \\
\hline $\ln (\operatorname{Inhabitants})^{*} \operatorname{In}(\mathrm{C} 4)$ & & & & & -0.237 & -3.34 & & \\
\hline Constant & -6.319 & -30.95 & -8.375 & -14.72 & -10.551 & -5.55 & -10.326 & -6.31 \\
\hline No. Obs. & 121 & & 121 & & 121 & & 121 & \\
\hline $\mathrm{R}^{2}$-adjusted & 0.957 & & 0.962 & & 0.960 & & 0.954 & \\
\hline
\end{tabular}

Panel B of Table 1 presents the regression results. Specification 1 shows that population density (positively) and market concentration (negatively) affect station density. The coefficient on $\ln D_{k}$ of $0.84(\mathrm{t}=49.01)$ implies that for each percentage increase in the number of inhabitants per sqkm the number of gasoline stations increases by around 0.8 percent per sqkm. This conforms to predictions of models of spatial competition that the number of outlets increases less than proportional to consumer density, since the greater proximity of shops increases competition between them and thus reduces the equilibrium price. The negative and significant coefficient on $\ln H E R F_{k}$ suggests that increases in concentration, e.g. via mergers, induce exit of stations. The adjusted $\mathrm{R}^{2}$ is more than $95 \%$.

Specification 2 includes an interaction term of $\ln D_{k}$ and $\ln H E R F_{k}$. The negative and significant coefficient estimate on this interaction term implies that the negative (exitinducing) effects of higher concentration increase with population density. We estimate that increases in concentration induce exit of stations in all districts except for the $10 \%$ districts with the lowest population density. Therefore, the largest exit-inducing effects of increasing concentration are witnessed in cities. This is consistent with fixed costs relative to exit costs being highest in cities, since high property prices in cities imply that outside opportunities for the station owner, e.g. alternative uses of the station area, are good. 
Specification 3 replaces $H E R F$ with $C 4$, with no change in (qualitative) results. On the contrary, the interaction term of $\ln D_{k}$ and $\ln C 4_{k}$ affects station density even more negatively, consistent with $C 4$ being able to measure oligopolistic interaction.

Finally, specification 4 instruments the Herfindahl index as well as the interaction term with variables proxying for differential cost and demand conditions, and estimates by 2SLS. The instruments include nine federal state dummies, the overall number of cars as well as the number of cars per inhabitant in district $k$, the average income level in district $k$, and the area share of alps and wood in district $k$. These instruments strike us to be plausible determinants of market concentration, and yet are exogenous to station density for sure. Cost and demand conditions systematically affect concentration: For example, a larger market size or lower fixed costs lead to a less concentrated market structure in most models of IO. Also the regulatory environment varies across the nine federal states in Austria, which may affect market concentration. ${ }^{10}$ The qualitative results are unaltered, however, using 2SLS, the interaction term is even more negative than in the corresponding OLS regression. Therefore, possible endogeneity of concentration does not drive our results.

\section{Conclusions}

We find that more concentrated markets in spatially differentiated industries display less product variety. This negative effect of market concentration is present in nearly all markets except in very sparsely populated markets. This suggests that fixed entry and exit costs are key determinants of the effects of market concentration on product variety.

\footnotetext{
${ }^{10}$ For example, environmental legislation differs across federal states, which affects fixed costs.
} 
Our findings have important implications for empirical merger analysis. The structural analysis of the effects of mergers should account for changes in product variety. Using premerger outlet-specific data to estimate the elasticity of demand, and ignoring the possibility that outlets could be closed due to the merger, underestimates market power of the remaining outlets. Mergers are likely to have both, price and product variety effects.

\section{References}

Berry, S. T. and J. Waldfogel, 2001, Do Mergers Increase Product Variety? Evidence From Radio Broadcasting, The Quarterly Journal of Economics 116, 1009-1025.

Baker, J. B. and T. F. Bresnahan, 1985, The Gains from Merger or Collusion in ProductDifferentiated Industries, Journal of Industrial Economics 33(4), 427-444.

Bresnahan, T. F., 1989, Empirical studies of industries with market power, in R. Schmalensee and R. D. Willig (eds.) Handbook of Industrial Organization, Vol II, Elsevier Science Publishers B.V.

Evans,W. N., Froeb, L. M., Werden, G. J., 1993. Endogeneity in the Concentration-Price Relationship: Causes, Consequences, and Cures. Journal of Industrial Economics Vol. XLI, No. 4, 431-438.

Genesove, D. and W. P. Mullin, 1998, Testing static oligopoly models: conduct and cost in the sugar industry, 1890-1914, RAND Journal of Economics, Vol. 29, No. 2, 355-377.

Heywood, J.S., Monaco, K. and Rothschild, R., 2001, Spatial price discrimination and merger: the N-firm case. Southern Economic Journal 67, 672-684.

Ivaldi, M., G. McCullock and C. Linari, 2002, U.S. Railroad Mergers: A Structural Econometric Perspective, presented at the EARIE 2002 meeting in Madrid.

Ivaldi, M. and F. Verboven, 2002, Quantifying the Effects from Horizontal Mergers in European Competition Policy, CEPR WP No. 2697. 
Martinez-Giralt, X., and D. Neven, 1988, Can price competition dominate market segmentation? Journal of Industrial Economics 36, 431-442.

Netz, J.S. and B.A. Taylor, 2002, Maximum or minimum product differentiation? Location patterns of retail outlets. Review of Economics and Statistics 84, 162-175.

Nevo, A., 2001, Measuring Market Power in the Ready-to-Eat Cereal Industry, Econometrica, 69(2), 307-342.

Pepall, L., Richards, D.J. and Norman, G., 2002, Industrial Organization: Contemporary Theory and Practice, 2e, South-Western, Mason, Ohio.

Pinkse, J., Slade, M. E., Brett, C., 2002. Spatial Price Competition: A Semiparametric Approach, Econometrica, 70 (3), 1111-1153. 


\section{CESifo Working Paper Series}

(for full list see www.cesifo.de)

1229 M. Hashem Pesaran, General Diagnostic Tests for Cross Section Dependence in Panels, July 2004

1230 Wladimir Raymond, Pierre Mohnen, Franz Palm, and Sybrand Schim van der Loeff, An Empirically-Based Taxonomy of Dutch Manufacturing: Innovation Policy Implications, July 2004

1231 Stefan Homburg, A New Approach to Optimal Commodity Taxation, July 2004

1232 Lorenzo Cappellari and Stephen P. Jenkins, Modelling Low Pay Transition Probabilities, Accounting for Panel Attrition, Non-Response, and Initial Conditions, July 2004

1233 Cheng Hsiao and M. Hashem Pesaran, Random Coefficient Panel Data Models, July 2004

1234 Frederick van der Ploeg, The Welfare State, Redistribution and the Economy, Reciprocal Altruism, Consumer Rivalry and Second Best, July 2004

1235 Thomas Fuchs and Ludger Woessmann, What Accounts for International Differences in Student Performance? A Re-Examination Using PISA Data, July 2004

1236 Pascalis Raimondos-Møller and Alan D. Woodland, Measuring Tax Efficiency: A Tax Optimality Index, July 2004

1237 M. Hashem Pesaran, Davide Pettenuzzo, and Allan Timmermann, Forecasting Time Series Subject to Multiple Structural Breaks, July 2004

1238 Panu Poutvaara and Andreas Wagener, The Invisible Hand Plays Dice: Eventualities in Religious Markets, July 2004

1239 Eckhard Janeba, Moral Federalism, July 2004

1240 Robert S. Chirinko, Steven M. Fazzari, and Andrew P. Meyer, That Elusive Elasticity: A Long-Panel Approach to Estimating the Capital-Labor Substitution Elasticity, July 2004

1241 Hans Jarle Kind, Karen Helene Midelfart, Guttorm Schjelderup, Corporate Tax Systems, Multinational Enterprises, and Economic Integration, July 2004

1242 Vankatesh Bala and Ngo Van Long, International Trade and Cultural Diversity: A Model of Preference Selection, July 2004 
1243 Wolfgang Eggert and Alfons J. Weichenrieder, On the Economics of Bottle Deposits, July 2004

1244 Sören Blomquist and Vidar Christiansen, Taxation and Heterogeneous Preferences, July 2004

1245 Rafael Lalive and Alois Stutzer, Approval of Equal Rights and Gender Differences in Well-Being, July 2004

1246 Paolo M. Panteghini, Wide vs. Narrow Tax Bases under Optimal Investment Timing, July 2004

1247 Marika Karanassou, Hector Sala, and Dennis J. Snower, Unemployment in the European Union: Institutions, Prices, and Growth, July 2004

1248 Engin Dalgic and Ngo Van Long, Corrupt Local Government as Resource Farmers: The Helping Hand and the Grabbing Hand, July 2004

1249 Francesco Giavazzi and Guido Tabellini, Economic and Political Liberalizations, July 2004

1250 Yin-Wong Cheung and Jude Yuen, An Output Perspective on a Northeast Asia Currency Union, August 2004

1251 Ralf Elsas, Frank Heinemann, and Marcel Tyrell, Multiple but Asymmetric Bank Financing: The Case of Relationship Lending, August 2004

1252 Steinar Holden, Wage Formation under Low Inflation, August 2004

1253 Ngo Van Long and Gerhard Sorger, Insecure Property Rights and Growth: The Roles of Appropriation Costs, Wealth Effects, and Heterogeneity, August 2004

1254 Klaus Wälde and Pia Weiß, International Competition, Slim Firms and Wage Inequality, August 2004

1255 Jeremy S. S. Edwards and Alfons J. Weichenrieder, How Weak is the Weakest-Link Principle? On the Measurement of Firm Owners' Control Rights, August 2004

1256 Guido Tabellini, The Role of the State in Economic Development, August 2004

1257 François Larmande and Jean-Pierre Ponssard, EVA and the Controllability-congruence Trade-off: An Empirical Investigation, August 2004

1258 Vesa Kanniainen and Jenni Pääkkönen, Anonymous Money, Moral Sentiments and Welfare, August 2004

1259 Panu Poutvaara and Andreas Wagener, Why is the Public Sector More Labor-Intensive? A Distortionary Tax Argument, August 2004 
1260 Lars P. Feld and Stefan Voigt, Making Judges Independent - Some Proposals Regarding the Judiciary, August 2004

1261 Joop Hartog, Hans van Ophem, and Simona Maria Bajdechi, How Risky is Investment in Human Capital?, August 2004

1262 Thomas Eichner and Rüdiger Pethig, Efficient Nonanthropocentric Nature Protection, August 2004

1263 David-Jan Jansen and Jakob de Haan, Look Who's Talking: ECB Communication during the First Years of EMU, August 2004

1264 David F. Bradford, The X Tax in the World Economy, August 2004

1265 Hans-Werner Sinn, Migration, Social Standards and Replacement Incomes. How to Protect Low-income Workers in the Industrialized Countries against the Forces of Globalization and Market Integration, August 2004

1266 Wolfgang Leininger, Fending off one Means Fending off all: Evolutionary Stability in Submodular Games, August 2004

1267 Antoine Bommier and Bertrand Villeneuve, Risk Aversion and the Value of Risk to Life, September 2004

1268 Harrie A. A. Verbon and Lex Meijdam, Too Many Migrants, Too Few Services: A Model of Decision-making on Immigration and Integration with Cultural Distance, September 2004

1269 Thomas Eichner and Rüdiger Pethig, Economic Land Use, Ecosystem Services and Microfounded Species Dynamics, September 2004

1270 Federico Revelli, Performance Rating and Yardstick Competition in Social Service Provision, September 2004

1271 Gerhard O. Orosel and Klaus G. Zauner, Vertical Product Differentiation When Quality is Unobservable to Buyers, September 2004

1272 Christoph Böhringer, Stefan Boeters, and Michael Feil, Taxation and Unemployment: An Applied General Equilibrium Approach, September 2004

1273 Assaf Razin and Efraim Sadka, Welfare Migration: Is the Net Fiscal Burden a Good Measure of its Economics Impact on the Welfare of the Native-Born Population?, September 2004

1274 Tomer Blumkin and Volker Grossmann, Ideological Polarization, Sticky Information, and Policy Reforms, September 2004

1275 Katherine Baicker and Nora Gordon, The Effect of Mandated State Education Spending on Total Local Resources, September 2004 
1276 Gabriel J. Felbermayr and Wilhelm Kohler, Exploring the Intensive and Extensive Margins of World Trade, September 2004

1277 John Burbidge, Katherine Cuff and John Leach, Capital Tax Competition with Heterogeneous Firms and Agglomeration Effects, September 2004

1278 Joern-Steffen Pischke, Labor Market Institutions, Wages and Investment, September 2004

1279 Josef Falkinger and Volker Grossmann, Institutions and Development: The Interaction between Trade Regime and Political System, September 2004

1280 Paolo Surico, Inflation Targeting and Nonlinear Policy Rules: The Case of Asymmetric Preferences, September 2004

1281 Ayal Kimhi, Growth, Inequality and Labor Markets in LDCs: A Survey, September 2004

1282 Robert Dur and Amihai Glazer, Optimal Incentive Contracts for a Worker who Envies his Boss, September 2004

1283 Klaus Abberger, Nonparametric Regression and the Detection of Turning Points in the Ifo Business Climate, September 2004

1284 Werner Güth and Rupert Sausgruber, Tax Morale and Optimal Taxation, September 2004

1285 Luis H. R. Alvarez and Erkki Koskela, Does Risk Aversion Accelerate Optimal Forest Rotation under Uncertainty?, September 2004

1286 Giorgio Brunello and Maria De Paola, Market Failures and the Under-Provision of Training, September 2004

1287 Sanjeev Goyal, Marco van der Leij and José Luis Moraga-González, Economics: An Emerging Small World?, September 2004

1288 Sandro Maffei, Nikolai Raabe and Heinrich W. Ursprung, Political Repression and Child Labor: Theory and Empirical Evidence, September 2004

1289 Georg Götz and Klaus Gugler, Market Concentration and Product Variety under Spatial Competition: Evidence from Retail Gasoline, September 2004 